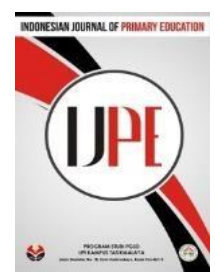

Vol. 2, No. 1 (2018) 72-77 ISSN: 2597-4866

Indonesian Journal of Primary Education

\title{
Pengaruh PBL terhadap Kemandirian Belajar Siswa SD
}

\author{
Ani Susilowati \\ Universitas Negeri Yogyakarta \\ *Corresponding author: anisusilowati25@gmail.com
}

Diterima 6 Mei 2018; Direview 9 Mei 2018; Diterima 17 Mei 2018

Diterbitkan online 4 Juni 2018

\begin{abstract}
Renewal of education in Indonesia is necessary to be aligned with the development of science and technology. Educational problems are changing attitude and conventional learning system in education. Primary School Teachers as the spearhead of the success of the education process in Indonesia. Therefore, teachers must be active and creative in finding and finding and developing education and teaching system so as to meet the students' needs optimally in the learning process. This study aims to involve students in learning to solve a problem relevant to the material or problems that exist around the students. The result is expected that students can gain a real learning experience. Students can also develop self-learning skills by seeking information through relevant sources to solve a problem related to the subject matter. The research method used is Nonequivalent Control Group Pretes-Postes Design. Conducted pretest before being treated, treatment results can be known more accurately because it can compare with the situation before being treated. This study shows that children's bad habits in learning have an impact on low learning achievement. Prior to complete treatment $48 \%$ of students. After doing the treatment by using Problem Based learning model has increased, to $86,96 \%$ of students who have above average learning achievement. Based on the research, the use of Problem Based Learning (PBL) model can foster self-reliance in grade $V$ elementary school students.
\end{abstract}

Keywords: Problem Based Learning, Learning Independence.

\begin{abstract}
Abstrak
Pembaharuan pendidikan di Indonesia sangat diperlukan agar sejajar dengan perkembangan ilmu pengetahuan dan teknologi. Permasalahan pendidikan yaitu mengubah sikap maupun sistem pembelajaran yang konvensional dalam pendidikan. Guru Sekolah Dasar sebagai ujung tombak keberhasilan proses pendidikan di Indonesia. Oleh karena itu, guru harus aktif dan kreatif dalam mencari dan menemukan serta mengembangkan sistem pendidikan dan pengajaran sehingga dapat memenuhi kebutuhan siswa secara optimal dalam proses pembelajaran. Penelitian ini bertujuan untuk melibatkan siswa dalam belajar memecahkan suatu permasalahan yang relevan dengan materi atau permasalahan yang ada disekitar siswa. Hasilnya diharapkan siswa dapat memperoleh pengalaman belajar yang nyata. Siswa juga dapat mengembangkan kemampuan belajar mandiri dengan cara mencari informasi-informsi melalui sumber-sumber yang relevan untuk memecahkan suatu masalah yang berkaitan dengan materi pelajaran. Metode penelitian yang digunakan adalah Nonequivalent Control Group Pretes-Postes Design. Dilakukan pretest sebelum diberi perlakuan, hasil perlakuan dapat diketahui lebih akurat karena dapat membandingkan dengan keadaan sebelum diberi perlakuan. Penelitian ini menunjukkan bahwa kebiasaan buruk anak dalam belajar berdampak terhadap prestasi belajar yang rendah. Sebelum dilakukannya treatment siswa yang tuntas hanya 48\%. Setelah dilakukannya treatment dengan menggunakan model Problem Based learning mengalami peningkatan, menjadi 86,96\% siswa yang memiliki prestasi belajar diatas rata-rata. Berdasarkan penelitian tersebut penggunaan model Problem Based Learning (PBL) dapat menumbuhkan kemandirian belajar siswa kelas V Sekolah Dasar.
\end{abstract}

Kata Kunci: Problem Based Learning, Kemandirian Belajar.

\section{PENDAHULUAN}

Pendidikan merupakan aspek yang sangat penting bagi kehidupan karena dengan adanya pendidikan kita mendapatkan ilmu yang bermanfaat. Ilmu merupakan pengetahuan tentang suatu hal, dan untuk mendapatkan ilmu atau pengetahuan dapat diperoleh melalui pendidikan. Kegiatan belajar sebagai upaya memperoleh pengalaman serta kemampuan baru dalam kehidupan. Dalam 
pencapaiannya, perlu adanya upaya dalam pembelajaran yang meliputi beberapa aspek diantaranya aspek pengetahuan, ketrampilan, dan sikap. Ada banyak faktor yang mempengaruhi tercapainya pendidikan yang baik yaitu faktor eksternal dan faktor internal. Faktor eksternal berupa pendekatan belajar guru dan metode mengajar guru dalam memberikan pembelajaran. Guru sebagai penentu ketercapaian mutu pendidikan. Sedangkan faktor internalnya berupa kecerdasan, minat, bakat, dan motivasi.

Rendahnya motivasi belajar siswa akan memengaruhi kemandirian belajar dan hasil belajar siswa. Siswa yang mempunyai kemandirian belajar yang baik dapat memecahkan masalahnya sendiri dan tidak terpengaruh dengan nilai, karena nilai bagi siswa bukan menjadi segalanya. Yang terpenting bagi siswa adalah memperoleh pengetahuan yang memberikan bagi dirinya kelak. Siswa akan merencanakan tujuan belajarnya, memanfaatkan lingkungan sekitar sebagai media belajar, serta dapat mengatur waktu untuk belajar dan bermain.

Salah satu bentuk ketidak mandirian siswa dalam belajar adalah menyontek. Berdasarkan hasil survei oleh Litbang Media Group yang dilakukan pada tanggal 19 April 2007 di enam kota besar yaitu Makassar, Surabaya, Yogyakarta, Bandung, Jakarta dan Medan terhadap 480 responden dewasa, hasilnya menunjukkan bahwa kebanyakan peserta didik di tingkat sekolah maupun perguruan (tinggi hampir 70\%) pernah melakukan kecurangan akademik dalam bentuk menyontek (Desriana Rizki, 2015).

Keberhasilan suatu pembelajaran merupakan sesuatu yang diharapkan dalam pelaksanaan kegiatan belajar di sekolah. Keberhasilan pembelajaran di sekolah dasar diantaranya dapat dilakukan dengan menggunakan model maupun metode pembelajaran yang inovatif yang melibatkan siswa dalam proses pembelajaran diantaranya dengan menggunakan model problem based learning. Pemilihan model belajar problem based learning dipilih karena melibatkan siswa dalam belajar memecahkan suatu permasalahan yang relevan dengan materi atau permasalahan yang ada disekitar siswa. Diharapkan siswa dapat memperoleh pengalaman belajar yang nyata. Siswa juga dapat mengembangkan kemampuan belajar mandiri dengan cara mencari informasiinformsi melalui sumber-sumber yang relevan untuk memecahkan suatu masalah yang berkaitan dengan materi pelajaran.

Penelitian ini bertujuan untuk menumbuhkan kemandirian belajar siswa SD melalui model Problem Based Learning.

\section{Model Problem Based Learning}

Problem based learning merupakan pembelajaran yang dirancang agar siswa dapat mengembangkan kemampuannya dalam memecahkan masalah yang berkaitan dengan suatu materi yang diajarkan oleh guru. Model Problem based learning dipopulerkan oleh Barrows dan Tamblyn (1980) yang diterapkan di McMaster Medical School Kanada (Savin- 
Baden, 2007: 8) tentang kemampuan penalaran mahasiswa kedokteran dalam penyelesaian masalah dengan melibatkannya dalam proses belajar. Barrow (1996) Belajar berpusat pada siswa di bawah bimbingan guru, siswa harus bertanggung jawab atas keputusannya dalam belajar sendiri, mengidentifikasi apa yang perlu diketahui untuk lebih mengerti dan mengelola masalah dalam pembelajaran dan menentukan di mana akan mendapatkan informasi itu (buku, jurnal, fakultas, sumber informasi on-line, dst). Hartman. Et al. (2013: 1) "Problem Based Learning $(P B L)$ is an instructional approach that privides learnes with opportunities to identify solutions to ill-structured, real-world problem", suatu pendekatan instruksional yang memberi peserta didik kesempatan untuk mengidentifikasi solusi terhadap masalah dunia nyata yang tidak terstruktur.

Model Problem Based Learning (PBL) adalah suatu model pembelajaran berdasarkan masalah yang disajikan secara sistematis oleh guru yang berkaitan dengan kehidupan nyata, kemudian siswa diarahkan untuk menyelesaikan masalah tersebut dari berbagai perspektif. Dengan maksud untuk menyusun pengetahuan sendiri tentang cara berpikir kritis, kemampuan pemecahan masalah, memperoleh pengetahuan, dan konsep yang esensial dari materi pelajaran yang di pelajari.

\section{Kemandirian Belajar}

Kemandirian belajar sebagai salah satu komponen penting dalam pendidikan. Kemandirian belajar merupakan kemampuan yang dimiliki oleh siswa sebagai pemegang kendali, pengambil keputusan atau pengambil inisiatif atas belajarnya sendiri. Jika seseorang memiliki peluang untuk mengembangkan kemandirian belajarnya secara maksimal maka dia akan dapat mengelola belajarnya dengan baik sehingga hasil yang nantinya didapatkan akan optimal.

Kemandirian belajar merupakan aktivitas belajar yang tidak bergantung kepada orang lain serta mempunyai inisiatif sendiri tanpa bantuan orang lain dalam menentukan tujuan, metode, sumber belajar, dan evaluasi hasil belajar, serta bertanggungjawab atas diri sendiri. Paulina Panen (2000: 5-10) menyatakan bahwa siswa yang mampu belajar mandiri adalah siswa yang dapat mengontrol dirinya sendiri, mempunyai motivasi belajar yang tinggi, dan yakin jika dirinya mempunyai wawasan yang luas dan luwes. Selain mempunyai kemampuan untuk mengontrol diri sendiri dengan baik, siswa juga harus mempunyai motivasi belajar yang tinggi agar bias memiliki kemandirian belajar yang baik. Sependapat dengan Haris Mudjiman (2007; 13) yang mengemukakan bahwa kemandirian merupakan sebuah kegiatan belajar yang dasari oleh niat untuk bisa menguasi dan mengerti sebuah kompetensi untuk mengatasi permasalahan yang ada dengan dasar pengetahuan yang yang telah didapatkan. Ketika siswa mendapat tugas dari guru yang cukup sulit, siswa yang tidak mempunyai motivasi belajar cenderung memilih untuk menyontek pekerjaan 
temannya. Namun, siswa yang mempunyai motivasi dan niat yang tinggi akan tetap berusaha untuk bias menyelesaikan tugasnya tersebut sesuai dengan kemampuannya sendiri.

Dari bebrapa pendapat diatas dapat disimpulkan jika kemandirian belajar adalah sebuah kegiatan belajar yang didasari dari dalam siswa dengan inisiatif dari dirinya sendiri tanpa mengandalkan bantuan orang lain. Motivasi yang timbul dari dalam dirinya bisa menjad semangat untuk menjadikan dirinya lebih baik. Siswa yang memiliki kemandirian belajar yang baik pasti memiliki motivasi belajar yang baik pula.

\section{METODE}

Penelitian ini termasuk dalam penelitian kuantitatif dengan jenis penelitian eksperimen semu (quasi eksperiment). Rancangan penelitian yang digunakan adalah Nonequivalent Control Group Pretes-Postes Design. Dalam rancangan ini dilakukan pretest sebelum diberi perlakuan, hasil perlakuan dapat diketahui lebih akurat karena dapat membandingkan dengan keadaan sebelum diberi perlakuan.

Penelitian ini dilaksanakan di SD gugus Yudistira yang terletak di Kecamatan Bima, Kabupaten Taksaka, yang terdiri atas 4 sekolah, yaitu

Tabel 1

\begin{tabular}{lrrl}
\hline \multirow{2}{*}{ Sekolah } & \multicolumn{2}{c}{ Jumlah } & \multirow{2}{*}{ Total } \\
\cline { 2 - 3 } & L & P & \\
\hline SD N Jaka Tingkir & 10 & 15 & 25 \\
\hline SD N Pasundan & 13 & 15 & 28 \\
\hline SD N Singasari & 10 & 14 & 24 \\
\hline SD N Gajahwong & 11 & 13 & 24 \\
\hline Jumlah & 44 & 57 & 101 \\
\hline
\end{tabular}

Teknik sampling yang digunakan adalah teknik simplerandom sampling yang artinya tiap unit dalam sampel mempunyai peluang yang sama untuk dipilih. Untuk pengambilan sampel diperoleh melalui pengundian. Setelah melakukan undian terpilih kelas V SDN Jaka tingkir, SDN Pasundan, dan SDN Singasari.

Teknik pengumpulan data pada penelitian ini adalah observasi dan skala kemandirian belajar dengan menggunakan skala Likert. Skala Likert digunakan untuk mengukur sikap, pendapat, dan persepsi seseorang atau kelompok tentang fenomena social (Sugiyono, 2013: 134). Pada skala Likert, subjek penelitian dihadapkan pada pernyataan yang bersifat positif maupun negatif dan diminta untuk menyatakan apakah "sangat sesuai", "sesuai”, "kurang sesuai”, "tidak sesuai", dan "sangat tidak sesuai". Analisis data menggunakan analisis deskriptif dan analisis inferensial.

\section{HASIL DAN PEMBAHASAN}

Sebagian besar siswa mengalami masalah dalam belajar. Permasalahan tersebut dikarenakan kebiasaan belajar yang buruk dan kurangnya motivasi dalam belajar. Hal ini terbukti dari sampel siswa, 52,00\% siswa memiliki prestasi belajar di bawah rata-rata kelas. Dan hanya $48,00 \%$ yang di atas ratarata kelas.

Tabel 2

\begin{tabular}{lcc}
\hline \multirow{2}{*}{ Kelas } & \multicolumn{2}{c}{$(\%)$} \\
\cline { 2 - 3 } & Tuntas & Tidak tuntas \\
\hline Kontrol & 48,00 & 52,00 \\
Eksperimen & 86,96 & 13,04 \\
\hline Berdasarkan & tabel diatas & menunjuk
\end{tabular}

Berdasarkan tabel diatas, menunjukkan bahwa kebiasaan buruk anak dalam belajar 
berdampak terhadap prestasi belajar yang rendah. Setelah dilakukannya treatment dengan menggunakan model Problem Based Learning $(P B L)$ mengalami peningkatan, menjadi $86,96 \%$ siswa memiliki prestasi belajar diatas rata-rata.

Dengan demikian untuk meningkatkan prestasi belajar anak, maka salah satunya dapat diatasi dengan cara memperbaiki kebiasaan buruk serta kesulitan dalam belajar yang dialami siswa melalui model Problem Based Learning.

Berdasarkan tes psikologi diperoleh hasil bahwa sebagian besar sampel penelitian ini memiliki tingkat kecerdasan umum (IQ) sedang atau rata-rata yaitu sebesar $(52,99 \%)$, sedangkan sisanya $(47,01 \%)$ termasuk kategori rendah atau di bawah rata-rata. Pada umumnya anak yang mempunyai IQ di bawah rata-rata maka akan memperoleh prestasi belajar yang rendah, sedangkan yang memiliki IQ rata-rata mempunyai peluang memperoleh prestasi belajar rata-rata maupun tinggi. Dari hasil belajar yang diperoleh, diketahui bahwa 52,00\% siswa memperoleh hasil belajar di bawah rata-rata kelas. Data ini menggambarkan bahwa setidaknya ada sekitar 4,99\% (52,00\% dikurangi 47,01\%) siswa termasuk kategori berprestasi di bawah potensinya (under achiever). Angka ini bermakna bahwa jika siswa mendapatkan pelayanan dan bimbingan belajar yang tepat dan baik di sekolah maupun di rumah, mampumencapai prestasi belajar yang tinggi.

Dalam penelitian ini menunjukkan bahwa ternyata lebih dari $4 \%$ tidak mampu mencapai prestasi yang tinggi atau berada di bawah rata-rata kelas padahal IQ normal, disebut sebagai 'under achiever'. Hal ini terkait dengan kebiasaan yang buruk dalam belajar. Berdasarkan hal tersebut, memperkuat kajian teori yang diungkapkan sebelumnya bahwa kebiasaan buruk dalam belajar berpengaruh terhadap hasil belajar. Oleh sebab itu dalam mengembangkan perubahan perilaku kebiasaan baik anak dalam belajar sangat penting dilakukan oleh guru guna menunjang proses belajar mengajar secara maksimal.

\section{SIMPULAN}

Kesimpulan dari penelitian ini adalah penggunaan model Problem Based Learning $(P B L)$ dapat menumbuhkan kemandirian belajar siswa Sekolah Dasar pada kelas V. Sehingga penelitian ini menunjukkan adanya kenaikan sebelum diberikan treatment dan setelah diberikan treatment. Dengan demikian penelitian ini tidak hanya mampu memperbaiki perilaku buruk anak dalam belajar tetapi juga meningkatkan prestasi belajar siswa.

Penelitian ini telah diusahakan dan dilaksanakan sesuai dengan prosedur ilmiah, namun demikian masih memiliki keterbatasan yaitu: faktor-faktor yang mempengaruhi perilaku siswa sekolah dasar dalam penelitian ini hanya terdiri dari dua variabel, yaitu menumbuhkan kemandirian siswa dan model Problem Based Learning (PBL), sedangkan masih banyak faktor lain yang mempengaruhi perilaku siswa dalam belajar. Pembelajaran 
dengan menggunakan Model Problem Based Learning $(P B L)$ belum pernah digunakan dalam proses pembelajaran di sekolah sehingga selama pelaksanaan proses belajar mengajar, pemberian model ini terkadang siswa kurang sesuai dalam melaksanakan prosedur yang telah diberikan guru. Penelitian ini merupakan penelitian kuasi eksperimen, sehingga kemandirian belajar siswa hanya dapat dilihat pada kelas yang dijadikan sampel penelitian saja.

Berdasarkan hasil penelitian yang diperoleh, penelitian ini dapat berimplikasi bagi pemerintah guna membantu menelusuri sekolah yang masih sulit dalam mengembangkan kemandirian belajar siswa agar tercapai pembelajaran yang berkualitas di Indonesia.

\section{REFERENSI}

Desriana Rizkia. 2015. Hubungan antara Selfefficacy dengan perilaku menyontek pada Mahasiswa Bina Nusantara [Online]. Diakses dari https://psychology.binus.ac.id/2015/09/ 22/hubungan-antara-self-efficacydengan-perilaku-menyontek-padamahasiswa-bina-nusantara/

Haris Mudjiman. (2007). Belajar Mandiri; Self Motivated Learning. Surakarta: UNS Press.

Hartman, B. K., Moberg, R. \& Lambert, M. J. (2013). Effectiveness of problem-based learning in introductory business course. Journal of Instructional Pedadogies [Online]. Diakses dari http://www.aabri.com/manuscripts/1316 11.pdf.

Paulina Panen. (2000). Belajar Mandiri (Mengajar di Perguruan Tinggi). Jakarta: PAU-PPAI Dirjen Dikti
Depdikbud.

Savin-Baden, Maggi (2007). A Practical guide to problem-based learning online. New York: Routledge Taylor \& Francis group.

Sugiyono. (2013). Metode Penelitian Pendidikan (Pendekatan Kuantitatif, Kualitatif, dan R\&D). Bandung: Alfabeta. 